\title{
Economic Ideas and North-South Preferential Trade Agreements in the Americas
}

\author{
Nicolás Pose*
}

\begin{abstract}
North-South Preferential Trade Agreements (PTAs) are an intensified version of the Uruguay round's bargain, in which developing countries gain access to developed countries' markets, expecting increase in inflows of foreign direct investment, but see their 'policy space' reduced (Shadlen, 2005). Focusing on United States' PTAs in the Latin American region, this article seeks to answer why some Latin American countries found this bargain attractive while others did not. I argue that modern PTAs generate uncertainty over their costs and benefits, because there are not standardized tools to estimate the impact of the 'trade-related' provisions they include. As a result, policymakers turn to their general ideas about economic development, which assign different meanings to them, producing differing decisions. Empirically, it is shown that the argument complements previous explanations based on structural and societal variables.
\end{abstract}

Keywords: Preferential trade agreements; Economic ideas; Uncertainty; North-South relations; Latin America.

\section{Resumen}

Los Acuerdos Preferenciales de Comercio (ACP) Norte-Sur son una versión intensificada de la negociación de la Ronda Uruguay, en la que los países en desarrollo obtienen acceso a los mercados de los países desarrollados, esperando un aumento en la entrada de inversión extranjera directa, pero a cambio ven reducido su espacio político (Shadlen, 2005). Enfocándose en los ACP de los Estados Unidos en la región latinoamericana, este artículo busca responder por qué algunos países latinoamericanos encontraron este intercambio atractivo, mientras que otros no. El argumento es que estos acuerdos generan incertidumbre sobre sus costos y beneficios, porque no existen herramientas estandarizadas para estimar el impacto de las disposiciones "relacionadas con el comercio" que incluyen. Como resultado, los formuladores de políticas recurren a sus ideas generales sobre el desarrollo económico, las que asignan diferentes significados a dichas disposiciones, produciendo decisiones diferentes. Empíricamente, se muestra que este argumento complementa las explicaciones previas basadas en variables estructurales y societales.

Palabras claves: Acuerdos preferenciales de comercio, Ideas económicas, Incertidumbre, Relaciones Norte-Sur, América Latina

*Assistant professor at the Programme of International Studies and the Department of Political Science, School of Social Sciences, Universidad de la República (Uruguay). Email: nicolas.pose@cienciassociales.edu.uy. Received: August 9th 2019; accepted: September 29th 2019. 
Nicolás Pose

Economic Ideas and North-South Preferential Trade Agreements in the Americas

\section{Introduction}

The increase in the number of North-South preferential trade agreements (PTAs) is a salient phenomenon of the international political economy, and Latin American (LA) countries have been involved in many PTAs as the southern partner during the last two decades. From their perspective, Shadlen (2005) points out that these deals are an intensified version of the 'Uruguay Round bargain' that ended with the creation of the World Trade Organization (WTO) (Ostry, 2002), since they involve an improvement in access to developed countries' markets, in exchange for the acceptance of 'trade-related' provisions that reduce the 'policy space' to deploy the type of measures that industrial latecomers have traditionally used to spur their economic development.

As some countries have found this bargain attractive while others have not, the question that emerges is what element explains this variation. In this paper, I propose an explanation that seeks to highlight an "omitted variable" in the literature (George and Bennett, 2005), related to the role of economic ideas. Specifically, I argue that the inclusion of trade-related provisions generates uncertainty over costs and benefits of a deal, and to overcome it, policymakers recur to their general ideas about how to promote economic development. But since there are different sets of economic ideas (neoliberalism, neoinstitutionalism, and structuralism) that provide different meaning to these provisions, assessments and therefore decisions vary according to their prevalence within decision-making circles. To examine this argument, I focus on PTAs proposed by the United States (US), because according to the literature these are the deals that include the most stringent trade-related provisions (Horn et al., 2010). I select two LA countries that faced the moderate structural pressures highlighted by the literature, but that nonetheless followed different paths: Chile and Uruguay.

Besides this introduction, the paper is organized in four sections. The following addresses the theoretical issues. First, building on Shadlen (2005), it explains why North-South PTAs are an intensified version of the Uruguay Round bargain; second, it reviews existing explanations of countries' decisions; and third, it develops the proposed argument. The third section addresses the methodological aspects and case selection criterion; and the fourth presents the case studies. The final section provides the conclusions.

\section{Theory and argument}

\section{North-South PTAs}

According to Ostry (2002), the Uruguay Round of the GATT was a 'grand bargain' between developed and developing countries. The former offered improved market access for light manufactures and agricultural products and in exchange demanded the inclusion of 'trade-related' disciplines resisted by developing countries such as services, investment and intellectual property rights. Shadlen (2005) argues that North-South PTAs are an intensified version of this bargain, in which developed countries offer better-than-most-favored-nation (MFN) market access, and a seal of approval that might attract additional inflows of foreign direct investment (FDI) ${ }^{1}$, but in return demand the inclusion of trade-related

${ }^{1}$ There is not academic agreement about the relationship between North-South PTAs and FDI inflows (see Büthe and Milner 
provisions that go beyond WTO requirements. Due to the setbacks to the trade-related agenda at the WTO, PTAs have become an attractive alternative (Gatthi, 2011).

Among developed partners, the US is the one that includes the largest number of enforceable provisions that go beyond WTO rules in its PTA model (Hoekman and Kostecki, 2009; Horn et al., 2010). Apart from including provisions like non-discrimination in government procurement, which is optional at the WTO, or competition policy, not addressed multilaterally, in services, unlike the European Union (EU), it negotiates on a negative list basis; in investment, apart from prohibiting export requirements, it also demands the ban of compulsory joint ventures, the inclusion of investor-state dispute settlement mechanisms and, unlike the EU, pre-establishment rights and coverage of portfolio capital; in intellectual property, it imposes more severe restrictions to issue compulsory licenses and enhance patent protection (Shadlen, 2005; Hoekman and Kostecki, 2009; Gallagher, 2013). These provisions reduce the 'policy space' of developing countries, understood as 'the flexibility under trade rules that provides nation states with adequate room to maneuver to deploy effective policies to spur economic development' (Gallagher, 2007 , p. 63). In other words, they compromise the possibility of implementing policies that both early developers and industrial latecomers deployed during their development efforts in order to create new productive capacities in more dynamic sectors and therefore alter their comparative advantages (Amsden, 2001; Chang, 2002). In exchange, the US offers preferential and stable market access for most manufacture tariff lines and, after transition periods, for most agricultural products. And although it avoids commitments in agricultural subsidies and technical barriers to trade (Salazar-Xirinachs, 2003), the deals substantially improve access for sensitive products for developing countries (Hoekman and Kostecki, 2009). Furthermore, they represent a 'seal of approval', which might be useful when seeking to attract international investors. Aware of its market size attractiveness, the US has offered the bargain worldwide, seeking to unleash a competitive dynamic (Zoellick, 2002). And while some Latin American countries have found the trade-off involved acceptable, others have not, which raises the question of what elements explain this variation.

\section{Existing explanations}

Some of the most prominent explanations of PTA formation, either general or from a developing country's perspective, highlight the importance of external or structural pressures as drivers of decisions. One of them builds on the domino theory of regionalism, according to which moving towards further integration in one country produces incentives in others to follow (Baldwin, 1993; 1997). Specifically, as some countries concede better-than-MFN treatment to each other, third countries suffer from trade diversion, which encourage exporters from these countries to pressure their governments to seek their own deals. As such, it is a mechanism of diffusion based on competition (Simmons et al., 2006). For LA, Sánchez-Ancochea (2008) has argued that this 'fear of exclusion' has increased pressures to sign PTAs with the US, because as neighbors with similar exporting profiles do so, the risk of trade diversion overcomes policy space concerns. And in a similar vein, Quiliconi (2014) states that the combination of these competitive dynamics with the absence of large internal markets push domestic producers to pressure their governments to seek deals with the US. Other external pressure highlighted is political trade dependence (PTD), identified by Shadlen (2008) and Manger and Shadlen (2014). It contends that most developing countries already enjoy preferential access to the US (and other developed markets),

2008 and Peinhardt and Allee 2012 for opposing results). 
Nicolás Pose

Economic Ideas and North-South Preferential Trade Agreements in the Americas

which is given by the Generalized System of Preferences (GSP) and GSP-like schemes. But these preferences are unstable, since they can be unilaterally removed. Therefore, if exports of a country rely extensively on these preferences, their government has an incentive to secure them through a PTA, even if this entails a significant reduction of policy space.

Both explanations give compelling reasons to understand some countries' decisions. However, they also leave some questions unanswered. For instance, competitive reactions cannot explain first-movers' decisions and, if PTAs cover only around $15 \%$ of global trade, there are some countries which may not face strong pressures from trade diversion. Similarly, if preferential exports are just a subset of exports to the US, and one assumes that some could survive without preferences, then their removal might be regarded as less problematic than the trade-related provisions the US demands in exchange. Even more importantly, if we observe countries facing similar levels of structural pressures and displaying different responses, then other factors must also be at play. In summary, in cases where structural pressures are moderate, we should pay more attention to domestic dynamics.

Related explanations focus on the influence of societal pressures on policymakers. The logic behind them is that since international trade has significant and predictable distributive effects, politicians will enact policies that favor the groups that support their electoral efforts (Milner and Judkins, 2004). In this vein, some propose that the government might be lobbied to 'protect exporters' (Baccini and Dur, 2012). Standard political economy explanations have assumed that seekers of protection are more able to overcome collective action problems and lobby governments, but empirical studies have shown this is not necessarily the case (Schonhardt-Bailey, 1991). Building on this idea, it has been argued that groups which stand to win from PTAs in developing countries are often better organized than those which lose from regulatory harmonization, since previous liberal reforms have strengthened their position vis-a-vis import-competing sectors. Besides, the prospects of being excluded from developed markets would activate their political mobilization (Shadlen, 2008). And reinforcing this logic is the fact that as policy space tools aim to create new sectors, these by definition cannot lobby for their preservation, which tilts the balance in favor of exporters in the traditional comparative advantage (Gallagher, 2008). However, policymakers often enjoy relative autonomy when deciding, and even lead rather than follow the private sector. According to Woll (2008), this is the case when uncertainty over cost and benefits of alternative policies lead to an intersubjective construction of preferences among businesses. In the end, the degree of relative autonomy of policymakers is an empirical question.

Among explanations that assume policymakers' relative autonomy, most assert that PTA formation is a strategic tool used by them in domestic struggles. This may involve signalling the electorate their commitment to general welfare (Mansfield and Milner, 2012), overcoming domestic opposition to market reforms, or locking in previous market reforms (Büthe and Milner, 2008; Manger, 2012; Solis et al., 2009). Relatedly, PTAs may be part of policymakers' strategies to becoming international trade hubs and taking a lead as attractive destinations to FDI (Katada and Solís, 2008), and an effort to join global value chains (WTO, 2011). The expectation behind these actions, of course, is that they will spur economic growth and development. However, while these motivations to join North-South PTAs are theoretically plausible, they do not explain why they operate only on some governments. Put it differently, these kinds of explanations, although relevant, have difficulties in explaining why some decide to join these deals, while others do not. 


\section{Economic ideas}

This article proposes an explanation based on the role of economic ideas as providers of meaning in situations of uncertainty. Ideas are worldviews, principled or causal beliefs (Goldstein and Keohane, 1993) and exert influence through different channels, such as: epistemic communities that offer advice about 'appropriate policies' backed by their authoritative knowledge (Haas, 1992); policy entrepreneurs that use ideas to alter political situations (Rodrik, 2014); or economists and other experts socialized in frameworks of thought that act as 'carriers' of them (Babb, 2003; Barnett and Finnemore, 2004; Chwieroth, 2007; 2010). Ideational scholars have argued that uncertainty creates space for ideas to influence decisions, because in contrast to risk, it does not admit the calculation of probabilities associated with choosing between different courses of action. Therefore, actors rely on more general frameworks of thought to guide their decisions (Blyth, 2002; Abdelal et al., 2010; Woll, 2008). And at the same time, they have shown how ideas help actors to interpret the environment in which they live by providing meanings to the situations they face (Abdelal et al., 2010; Chwieroth, 2010). By combining these insights, we can offer an ideational explanation for the observed variation of decisions towards North-South PTAs among governments that were not fully constrained by external pressures.

Such explanation departs from the observation made by Gallagher (2008) and Gathii (2011) that 'neoliberal ideas' and North-South PTA formation may be associated. Gathii (2011) stresses that PTAs are part of neoliberal policies, not simply forced by coercion from third parties, but also adopted by officials because they believe in their capacity to spur growth. He mentions various reasons why this happens: experts that carry neoliberal ideas, emulation and mimicking, and bounded rationality. Nevertheless, the author does not develop the causal mechanisms behind these reasons and fails to present empirical evidence. While Gallagher (2008) notes some correspondence between neoliberal governments and PTA formation, he also finds some preliminary contradictory evidence and does not show a causal link between ideas and decisions. Furthermore, his paper does not weight this variable against the main structural and societal hypotheses it also presents.

I argue that the prevalence of different general ideas about economic development among policymakers can explain variation in decisions about North-South PTAs, because as the trade-related provisions they include generate uncertainty over potential costs and benefits, ideas assign meanings to these disciplines and therefore help policymakers to make sense of the issues at stake. The uncertainty about the effect of the trade-related provisions is given by the fact that unlike tariff reductions, whose impact on growth can be estimated by using computable general equilibrium (CGE) models, there is not a standardized and widely accepted way of estimating the impact of their adoption. Or to put it differently, there is not a similar device to CGE models to estimate the impact of the reduction of policy space (Gallagher, 2008; Scott and Wilkinson, 2011) ${ }^{2}$. Therefore, policymakers turn to their ideas about economic development to 'give meaning' to these fact, but there is not agreement among schools of economic thought on how development is best pursued, and in particular whether the tools of the policy space promote or hinder development.

In LA, three schools are usually identified: the classic neoliberalism (based on New Classical Economics and monetarism) and structuralism (based on the work of the Economic Commission for Latin America)

${ }^{2}$ For example, the use of tariff equivalents for trade in services is deemed as highly speculative (Roberts and Heydon 2012). 
Nicolás Pose

Economic Ideas and North-South Preferential Trade Agreements in the Americas

(Chwieroth, 2010), and neo-institutionalism (based on New Institutional Economics), a more recent school that has informed much of the Post-Washington Consensus development thinking (Saad-Filho, 2010; Babayev, 2015). For structuralism, development is encouraged by deploying tools to shift the comparative advantage from traditional to more dynamic and technological-intensive sectors, and for this purpose it recommends the use of government procurement to favor national producers, the presence of state-run monopolies in areas with potential technological spillovers, and loose intellectual property right regimes that allow imitation. Therefore, it gives a positive meaning to the concept of policy space and its preservation. On the contrary, neoliberalism relies on market mechanisms and price signals to achieve an efficient allocation of resources in the economy, and considers that the policies mentioned above generate negative distortions and rent-seeking opportunities. Whereas neo-institutionalism adds the importance of strong, stable and predictable 'rules of game', such as defined property rights, as preconditions for markets to work. But like neoliberalism, it does not prescribe the kind of industrial policies supported by structuralists. Therefore, these schools do not identify a trade-off between expanding market access and reducing policy space, since the meaning given to this space is negative or neutral at best.

The implication is that the ideas about economic development held by policymakers at the time NorthSouth PTAs become an option are crucial to understand variation in developing countries' decisions. These actors act as 'carriers' of the ideas acquired through professional training and socialization, their ties with epistemic communities and their own personal experiences. And once in power, in front of decisions surrounded by uncertainty, they assign meaning and make choices based on them. Thus, for structuralist policymakers the loss of policy space caused by US PTAs is too costly, so they will try to avoid joining them. On the contrary, for neoliberal or neo-institutional policymakers there is no such cost associated with it -and in fact it may represent even an opportunity for reform, as some authors reviewed have pointed out-, so they will seek a deal.

\section{Method and case selection}

In LA, 11 countries have joined PTAs with the US. With the exception of Mexico, all were signed between 2003 and 2006, a period when President George W. Bush got fast track authority from the US Congress. Table 1 displays this information, together with data for a set of variables that derive from the theoretical discussion. The data reveals considerable variation among countries. All cases with PTD levels above $20 \%$ signed PTAs, but others with less than $5 \%$ also did so, while a case with almost $10 \%$ refrained from it. The majority had right or center-right governments, but Chile and Dominican Republic joined under left-of-center administration. Most were open to trade, but more closed economies like Colombia also signed it, while others comparatively open did not.

In order to assess the explanatory power of my argument, I conduct two case studies on countries that displayed similar characteristics, including the absence of strong external pressures, but that nonetheless took different paths: Chile and Uruguay. As table 1 show, neither of them depended heavily on US preferences. Furthermore, they were not experiencing competitive diffusion pressures or 'fear of exclusion': Chile was a 'first-mover' in the region, which means that, contrary to what Stallings (2009) asserts, a defensive aim of avoiding trade diversion could not have been a driver of the decision; and 
Uruguay's main exports to world markets -beef, grains and dairy products-, do not compete with the ones of Andean and Central American countries that were signing deals with the US at the time (RyanCollins 2009: 16-19). Therefore, the governments of Chile and Uruguay enjoyed a fair amount of relative agency when making their choices.

Table 1: US PTAs with LA countries and data for selected variables

\begin{tabular}{|c|c|c|c|c|c|}
\hline Country & $\begin{array}{l}\text { PTA with } \\
\text { US }\end{array}$ & Year & PTD (\%)* & $\begin{array}{l}\text { Trade/GDP } \\
(\%)^{* *}\end{array}$ & Ideology $* * *$ \\
\hline Argentina & No & - & 1 & 41 & - \\
\hline Bolivia & No & - & 9.3 & 52.9 & - \\
\hline Brazil & No & - & 3.8 & 28.5 & - \\
\hline Chile & Yes & 2003 & 1.8 & 66.5 & $\mathbf{L}$ \\
\hline Colombia & Yes & 2006 & 4.9 & 35.1 & $\mathrm{R}$ \\
\hline Costa Rica & Yes & 2004 & 11.9 & 83.4 & $\mathrm{R}$ \\
\hline $\begin{array}{l}\text { Dominican } \\
\text { Republic } \\
\end{array}$ & Yes & 2004 & 26.7 & 81.1 & $\mathrm{~L}$ \\
\hline Ecuador & No & - & 7.9 & 49.1 & - \\
\hline El Salvador & Yes & 2004 & 7.7 & 69.6 & $\mathrm{R}$ \\
\hline Guatemala & Yes & 2004 & 10.8 & 67 & $\mathrm{R}$ \\
\hline Honduras & Yes & 2004 & 21.2 & 125.2 & $\mathrm{R}$ \\
\hline Nicaragua & Yes & 2004 & 31.4 & 62.5 & $\mathrm{R}$ \\
\hline Panama & Yes & 2006 & 1.9 & 120.1 & $\mathrm{R}$ \\
\hline Paraguay & No & - & 0.8 & 93.5 & - \\
\hline Peru & Yes & 2006 & 8.7 & 38.3 & $\mathrm{R}$ \\
\hline Uruguay & No & - & 8.3 & 51.1 & - \\
\hline Venezuela & No & - & 2.3 & 51.5 & - \\
\hline
\end{tabular}

* Preferential exports to US as share of total exports. Average 1996-2001.

** Average 2002-2004.

*** $\mathrm{R}$ denotes center-right or right-wing governments, $\mathrm{L}$ denotes center-left or left-wing ones.

Source: Shadlen* (2008, p. 9); World Bank Development Indicators Database**; Debs and Helmke*** (2010).

At the time of deciding, both countries were governed by left-of-center administrations. Chile signed its PTA with the US in June 2003. The President was Ricardo Lagos of the Socialist Party (PSCh), which together with the centrist Christian Democratic Party (PDC) formed the Coalition of Parties for Democracy (Concertación), a left-of-center coalition established in the 1980s (Garretón, 2005). Whereas in Uruguay the offer from the US administration arrived in 2006, when socialist Tabaré Vázquez of the Broad Front (FA), a left-of-center coalition formed by left-wing and center-left parties (Panizza, 2008), was president of the country. 
Nicolás Pose

Economic Ideas and North-South Preferential Trade Agreements in the Americas

Apart from this, the countries share other commonalities. Economically, they are amongst the highest in terms of GDP per capita in LA. Besides, both are small open economies with a significant participation of trade in their economic activities, as shown by their trade to GDP ratios in table 1. Scholars frequently highlight the similarities of Chilean and Uruguayan political systems, since they are highly institutionalized democracies which rank at the top of quality of democracy indexes in LA (Barreda, 2011), have strong, stable and highly institutionalized political parties (Alcántara and Luna, 2004), which are central actors that mediate between politics and society (Valenzuela, 1995 for Chile; Buquet and Chasquetti, 2004 for Uruguay), and compete on an ideological basis, more similar to Western European democracies than to many LA ones (Alcántara and Luna, 2004).

These commonalities allow to follow Mill's 'method of comparison' reasoning: if cases are most similar in a large number of variables but produce a different outcome, then the differing variable(s) between them must be found for an explanation. To examine if the argument proposed in this paper is the differing variable, I conduct a case study for each country's decision. This involves identifying the beliefs of key policymakers, their ties with epistemic communities, but also their ties with pressure groups and societal bases of support, since this represents an alternative explanation. And crucially, tracing the process that led to the decision, from how the issue entered into the agenda, to which actors supported and opposed the proposal, to how the final outcome was produced. To do this, I draw on official documents, press material, and secondary literature.

\section{Case studies}

Chile

Chile embarked on a policy of unilateral trade liberalization in the mid-1970s as part of a broader program of market reforms that followed Pinochet's coup in 1973. These reforms were driven by the 'Chicago Boys', a group of Chilean economists trained in the University of Chicago at a time when Milton Friedman and others were developing the core of neoliberal economic ideas there (Hira, 1998; Silva, 2009). Until 1982 these economist were insulated from political pressures to pass reforms in a technocratic fashion (Montecinos, 2009), and although the crisis of that year opened the door for some business involvement (Silva, 1998), the strong recovery that followed also meant an influx of power and legitimacy for the Chicago Boys (Silva, 1991; Hira, 1998).

In 1990 Chile re-democratized. Concertación coalition won the election, and Patricio Aylwin from PDC became president. However, the economic model remained unchanged (Hira, 1998; Silva, 1998; Agüero, 2005). Furthermore, the democratic government maintained, and even reinforced, the role of economists and the technocratic style (Silva, 1991; Montecinos, 2009). Silva (1991, p. 407) documents the composition of Aylwin's economic team, where economists with $\mathrm{PhDs}$ from top foreign universities, especially US ones, clearly prevail. The majority of these economists, particularly in the Finance Ministry, came from CIEPLAN, a think tank close to PDC (Silva, 1991). Among them was Alejandro Foxley (PhD, University of Wisconsin), who was appointed Finance Minister. They had been critics of the Chicago Boys in the 1970s, but after the post-1983 success they came to value their capacity to foster economic growth (Silva, 2009). As a result, according to Hira (1998, p. 141): 
Latin American Journal of Trade Policy 4 (2019) - Universidad de Chile

With the end of the dictatorship, both the current DC and the renovated socialists who dominate the PS and its sister party, the PPD, have been convinced of the optimality of the system. Although they call for some modification for greater redistribution, they do not promote any substantial changes in the neoliberal model that might affect economic growth.

Likewise, Montecinos states that "Chilean economists have been particularly receptive to homogenizing currents in economics. (...) They seem certain that on the road to development and prosperity there are not paths leading back to the statist past" (2009, p. 182). Of course, this included trade liberalization (Agüero, 2005). However, in a context where the number of PTAs worldwide was on the rise, the new government decided to add this tool to complement, but not substitute, unilateral liberalization. As a proof, when it signed the first bilateral agreement in 1991, it also reduced MFN tariffs from 15\% to $11 \%$ (Porras, 2003, p. 34). This strategy of continuing with the policy of unilateral tariff reduction plus the addition of signing multiple PTAs generated consensus among economists from Concertación and the former regime, producing what Rojas (2015) calls the epistemic community of 'open regionalism'.

Since US President George H. Bush launched a free trade agenda for the Americas in 1990, the main PTA sought by Concertacion governments was with the US. And all the evidence suggests that the idea came from CIEPLAN economists who occupied key positions in the Finance Ministry. For example, Montecinos (2009, p. 150) asserts:

Under President Aylwin (1990-94) the rivalry between diplomats and the economic team became intense. Chile was then the first to adhere to a US-proposed hemispheric free trade area in the Americas. Many expected that negotiations to join NAFTA (...) would succeed. Tellingly, those negotiations were managed from the Finance Ministry.

Moreover, an edited volume by CIEPLAN economists in 1992, some of them advisors to the Finance Ministry, highlighted the benefits of signing a deal with the US, which was the world biggest economy, Chile's main trading partner, and represented a model of free-market economy. And in contrast, it emphasized the risks of joining an agreement with the more protectionist and macro-economically volatile Southern Common Market (Mercosur) (Butelmann and Meller, 1992).

It could be counter-argued that the pressure of exporting business groups, whose power was enhanced after two decades of pro-business policies, and who had an interest in getting preferential access to Chile's most important market (20\% of total exports), was the driver in the search for a deal with the US. Nonetheless, the most powerful sectoral business associations in the 1990s preferred to, and lobbied for, joining Mercosur rather than NAFTA (Maxfield, 2003, p. 78-79; Schneider, 2004, p. 227). As Schneider (2004) explains, exports to the US were concentrated in a few products, while those to Mercosur were more diversified and therefore encompassed more interests. Besides, the preferential margin given by an agreement with Mercosur was greater, because tariffs were higher. On top of that, many sectors felt they were competitive enough for Mercosur but not for the US market. And since the US Congress was opposed to the incorporation of Chile to NAFTA at that time, President Eduardo Frei finally signed an association agreement with Mercosur (Agüero, 2005).

But as their preferred option became temporarily unavailable, Frei's economic team, also led by economists trained in top US universities (Montecinos, 2009, p. 160-161), decided to sign PTAs with Canada (1996) and Mexico (1998) using the NAFTA framework (i.e. including trade-related provisions) 
Nicolás Pose

Economic Ideas and North-South Preferential Trade Agreements in the Americas

in order to signal the US their stance (Garcé et al., 2016, p. 74-75). Tellingly, business groups paid little attention to these deals (Porras, 2003, p. 48). And simultaneously, the government reformed the office in charge of foreign economic relations in the Ministry of Foreign Affairs (DIRECON), replacing generalist diplomats with economists and giving it operational autonomy from the Ministry (Porras, 2003).

In 2000, Concertación won the elections again, but this time the coalition's candidate came from the PSCh partner. Rightly after assuming, President Lagos (2000-2006) found the offer from the US that Frei lacked, and in 2003, after a few months of negotiations, a deal was signed (Agüero, 2005). The fact that it was agreed by a left-leaning, non-neoliberal administration is puzzling for some scholars, who as a result conclude that other forces like structural or societal pressures must had been in place (e.g. Gallagher, 2008, p. 56). However, a closer inspection to the evidence shows that both Democrat Christians and Socialists in Chile had come to see the free-market economic policies that inherited as the only or most effective path to economic growth (Hira, 1998; Agüero, 2005; Montecinos, 2009) ${ }^{3}$, and their top economists were part of the consensus of the epistemic community of open regionalism (Rojas, 2015).

President Lagos himself was an economist with a PhD from Duke University, and set up an economic team with the same influence and profile than his predecessors (Porras, 2003). Nicolás Eyzaguirre (PhD candidate, Harvard University), member of the renovated Socialists, was appointed Finance Minister; Osvaldo Rosales, a trade economist and former advisor to Frei's campaign, director of DIRECON; and Andrés Bianchi (PhD Yale University), a former Central Bank governor, ambassador to the US. PDC figures who advocated the deal also occupied key positions in the cabinet and in Congress (e.g. Alejandro Foxley). Likewise, the renovated DIRECON staff backed the PTA on technical grounds, reinforcing the consensus at the political level.

The assessment of costs and benefits provided by policymakers highlights their reasoning. For Lagos (2008, p. 595), as Chile did not have an attractive internal market, it had to offer other issues, like services and government procurement, to persuade potential partners to open their markets. And Rosales, when reporting to the Foreign Affairs Commission in Congress, asserted that Chile exchanged offers in financial and telecommunications services, e-commerce and intellectual property, that were priorities to the US, for enhanced market access for agriculture and mining products -which in practice meant reducing the length of the transition period where the US would apply quotas-. Nonetheless, on many occasions he regarded these concessions more as an opportunity than as a cost, highlighting the potential gains from enhanced competition and reinforced legal certainties that would attract FDI (Congress of Chile, 2003) -a similar assessment can be found in Rosales (n.d.) ${ }^{4}$. Besides, in addition to having negotiated these trade-related provisions with less relevant trading partners like Mexico and Canada as a strategic preparation, they were seeking to include them in deals with other LA countries (Rosales, 2003), where Chile was clearly not demanded to do so. With this strategy, Rosales (n.d, p. 125-126) expected to improve efficiency in resource allocation, create trade and investment opportunities in traditional sectors,

\footnotetext{
${ }^{3}$ In combination with more active policies in the social realm, which differentiated them from the centre-right policy proposals. ${ }_{4}^{4}$ The main exception was the US demand to eliminate market-based capital controls to short-term foreign investment, which nonetheless were not in use at the time of negotiations. The final agreement greatly restricts, though does not eliminate, their eventual use (Agüero, 2005). An example of identification of policy space reduction is the difficulty faced by Chilean policymakers when seeking to regulate providers of financial, telecom and energy services (Manger, 2008).
} 
and also to encourage innovation and diffusion of technology to diversify exports. Put it in another way, the trade-related disciplines demanded by the US were not perceived as a policy space concern but, on the contrary, in many cases were the endogenous policy choices of Chilean governments, consistent with their development strategy, and the PTA with the US would only operate as a strong lock-in mechanism.

As further proof of the open regionalism consensus, the Freedom and Development Institute, main opposition's think tank (Moreno, 2010), also supported the agreement with the US, stating it would help to consolidate the Chilean free-market economic model (Guzmán, 2003). In Congress, the ratification vote showed an overwhelming support (77\% in the Senate and $84 \%$ in the Deputies Chamber), with just one dissenting Socialist lawmaker mentioning the reduction of policy space as a concern (Congress of Chile, 2003). The evidence also suggests that interest groups representation yields little insight to understand the government's decision. The majority of business associations -with the exception of traditional agriculture, part of the pharmaceutical industry and small business groups- now supported the deal; however, it was not their main priority. In $2000,75 \%$ of Chilean exports to the US were concentrated in four sectors (copper, fruits, fish and timber) (Solervicens, 2003), and according to their representatives, the main barrier to the US market was not tariff but antidumping measures and technical barriers, which were not solved by the PTA (Representative of Salmon industries in Congress of Chile, 2003, p. 45). Besides, It is hard to assert that the Lagos' government had an incentive in advancing particular business interests at a time when their associations where working close to the center-right opposition to win the following election (Silva, 2002). The natural ally of a Socialist government would have been organized labor, and indeed both Concertación parties had ties with the trade unions confederation CUT (Porras, 2003). Nevertheless, this does not explain the government's decision since CUT opposed the deal (Congress of Chile, 2003, p. 65). Rather, the initiative continued being propelled by Concertacion's economic policymakers who believed in the PTA's capacity to spur economic development, until a deal was finally achieved. Besides, it was supported by a broader economic consensus in Chile about the merits of the open regionalism strategy and a market-driven economy. Therefore, an examination of the whole process highlights how the ideas of policymakers assigned a neutral and even positive meaning to the reduction of policy space, driving them to actively seek a PTA with the US.

\section{Uruguay}

In the early 1990s, Uruguay significantly liberalized its external trade, cutting import duties and abolishing many non-tariff barriers (Panizza, 2008). In 1990 it also joined Mercosur, an agreement led by its two main trading partners at the time, Brazil and Argentina, and therefore became part of the external common tariff (CET) of the bloc. The average MFN CET is relatively high, but it is full of exceptions, so in practice the bloc does not work as a custom union (Porzecanski, 2010), a fact expressed by the presence of custom checks at the border, as well as by a bilateral PTA that Uruguay holds with Mexico. Besides, Uruguay extensively uses drawback and special importing schemes for intermediate products, thus its average applied MFN tariff has been consistently lower. In the early 2000s, President Jorge Batlle (Colorado Party), a historic promoter of economic liberalism in Uruguay, supported Bush's hemispheric trade proposal. As a result, Bush offered him to set up a Joint Commission for Trade and Investment (JCTI) in 2002. There, the idea of a PTA emerged, but Uruguay was dealing with the worst financial crisis of its history, so it was postponed. Instead, a bilateral investment treaty (BIT) was signed in 2004 (Porzecanski, 2010, p. 62-63). 
Nicolás Pose

Economic Ideas and North-South Preferential Trade Agreements in the Americas

After in that year, FA won the presidency for the first time in history and also obtained parliamentary majority. The coalition was composed of seven parties with parliamentary representation ${ }^{5}$, and all their leaders were appointed in cabinet. This greater dispersion than in Concertacion is partly explained by Uruguayan electoral rules, which allow parties to accumulate forces under the same lemma. President Vázquez chose Danilo Astori -leader of AU- for the Finance Ministry, and delegated him the design of economic policies. Astori, a well-known economist and long-time politician, set up an economic team of economists trained in the US and Europe (e.g Mario Bergara, PhD University of California Berkeley, as Deputy Finance Minister), which agreed on the view that lack of investment was the key impediment to growth in the country (Astori, 2005). And inspired on the developments of New Institutional Economics, they shared the idea that strengthening the 'rules of game', that is, building strong and credible institutions that provide economic actors with appropriate incentives, was the answer to overcame this constraint and set a path for economic development (Panizza, 2008; Garcé, 2014a) ${ }^{6}$.

Once in power, one of the first decisions of the government was to ratify the BIT the previous administration had signed with the US (after a minor renegotiation to overcome resistance within FA) (Porzecanski, 2010). After that, following talks with USTR officials in the JCTI, Astori proposed in early 2006 that Uruguay should negotiate a PTA with the US (Danza, 2006). He saw it as the next natural step to boost investors' confidence in the country. Besides, he and his team were disappointed by the functioning of Mercosur, because of the non-tariff barriers to intra-bloc trade frequently deployed by Argentina and Brazil'. Thus, they concluded that the 'Chilean way', that is, an association agreement with Mercosur without full membership, combined with bilateral PTAs with major economies, was the best policy option (Porzecanski, 2010; Garcé, 2014b). Overall, as Panizza (2008) explains: "For Astori’s “Third Way" approach, a free trade agreement would not only be crucial for boosting exports and attracting foreign investment but, more importantly, it would lock into place a market-friendly model of economic development” (p. 191). Whereas Vázquez, a medical doctor without in-depth knowledge of trade policy, supported his view (Garcé, 2014b).

However, unlike Chile, this perspective on economic development neither generated a consensus in FA nor in academia. As a consequence, four of the seven parties within FA opposed the PTA idea (RyanCollins, 2009, p. 20-21), including the first, third and fourth in parliamentary size. These parties converged on a view of economic development that was informed by the structuralist school of thought, which calls for a greater role of the state in steering resources to encourage innovation and create comparative advantages in new productive activities (Panizza, 2008; Garcé, 2014a). They were backed by a network of experts in innovation, which Garcé (2014b, p. 451) calls 'developmentalist epistemic community', integrated by economists but also engineers, development experts, political scientists, sociologists and historians, all of them with ties to the FA (indeed, one of the network spokesperson, Alberto Couriel, economist, was also a MPP-FA senator), who asserted that a PTA with the US would negatively affect innovation policies in the long run (Porzecanski, 2010).

\footnotetext{
5 In order of parliamentary size (biggest to smallest): Movement of Popular Participation (MPP); Uruguay Assembly (AU); Socialist Party (PSU); Vertiente Artiguista (VA); Progressive Alliance; New Space; Communist Party (PCU) (Porzecanski, 2010, p. 67).

${ }^{6}$ The most detailed application of New Institutional Economics to policy solutions in Uruguay can be found in the academic work of Bergara, e.g. (2003).

${ }^{7}$ At the time, the share of export to Brazil and especially Argentina were falling rapidly, and the US had become temporarily the first destination of Uruguayan exports (Porzecanski, 2010).
} 
These politicians and experts did not oppose increases in trade or FDI with the US, but the trade-related provisions of the PTA. Similar discrepancies had already arisen when the BIT ratification, but since Uruguay already had 25 BITs, and multinational companies with subsidiaries can treaty shop, they gave up their opposition after the renegotiation mentioned before. In contrast, a PTA involved far greater costs in terms of policy space (Porzecanski, 2010). The developmentalist experts produced, from official and semi-official positions, a set of studies (compiled in Quijano, 2006), in which they concluded that while a PTA with the US entailed some opportunities for traditional exports, these were outpaced by the costs of the provisions in services, government procurement and intellectual property that imposed too onerous constraints on the state. Thus, they recommended negotiating an agreement "centred exclusively on trade (tariffs and quotas) aspects" (Quijano, 2006, p. 13). These ideas resonated within FA parties, and were transmitted into the cabinet mainly by the Foreign Affairs Minister, Reinaldo Gargano (PSU) (Garcé, 2014b). In addition to this, Gargano also recurred to the potential consequences for Mercosur membership as a discursive weapon against the deal, since Uruguay exported products with higher addedvalue to this market (Porzecanski, 2010, p. 123).

Given the level of discrepancies, Vázquez set up an inter-ministerial commission (CIACEX), which would operate at both political and bureaucratic levels. With inputs from different departments, CIACEX made a technical report assessing the potential consequences of a deal, using the US-Peru PTA as a benchmark. The report identified offensive interests in beef, dairy and textile sectors, but also warned about the costs of liberalization of state-run monopolies of telecommunications and fuel distribution services, acceptance of new compromises in government procurement, and especially of the provisions on intellectual property rights that restricted the diffusion of knowledge (CIACEX, 2006). This enhanced the position of those opposing the deal (Porzecanski, 2010). Vázquez had limited understanding of these trade-related issues, but Astori and his team were clearly aware of them. However, requirements like liberalizing competition in the service sectors in which state-owned companies operate were not a cost in their view, since they were proposing those same policies as part of a program of reforms (Danza, 2006). The chapter about intellectual property, while maybe costly, was seen to be offset by potential gains. Nevertheless, even if Vázquez supported Astori's views, and could have counted on the support of opposition parties to ratify a deal in Parliament (Garcé, 2014b), he was not willing to follow a path which was opposed by the majority of his coalition. So, when Bush formally proposed to start negotiations towards a PTA, he turned down the offer. Instead, Vázquez suggested the idea of a 'trade (tariffs and quotas)-only' agreement, which was supported by FA, but rejected outright by the US (Porzecanski, 2010). Therefore, the countries did not sign a PTA.

As some FA parties maintain close ties with organized workers - especially PCU, and to some extent PSU (Yaffé, 2005)-, and the confederation of trade unions PIT-CNT strongly opposed the proposal, it could be argued that FA opposition was the result of interest representation. But MPP and AU, the two largest FA parties, which maintained only loose ties with PIT-CNT, differed between them in their positions. It could also be argued that $\mathrm{AU}$, which tended to represent more professional, middle-class constituencies (Panizza, 2008), promoted the deal because there were potential gains for these sectors (though the distributive consequences for professionals with close ties with the state were not evident). But VA, which appealed to a similar electorate, opposed the deal. Furthermore MPP, which represented nonorganized urban poor but also farmers, especially in the dairy sector, who would have clearly won from a PTA, also opposed it. More generally, business groups, with the exception of the association of 
Nicolás Pose

Economic Ideas and North-South Preferential Trade Agreements in the Americas

laboratories, converged on the support of the initiative (Symonds et al., 2006). This included those who stood to win, but, surprisingly, also those specialized in Mercosur markets (manufacture producers not competitive enough for world markets) that could have lost from a deteriorating relation with Mercosur partners. Overall, interest representation does not offer an alternative explanation of the dynamics within FA.

Finally, it has been argued that Mercosur membership was another decisive factor, since Argentina and Brazil did not appear willing to accept that Uruguay signed a PTA with the US and continued being part of the bloc (Porzecanski, 2010; Quiliconi, 2014). As seen before, Gargano recurred to this argument to strengthen the opposition to the deal, but this seemed more like a strategy to impose his view within FA. For the economic team, as revealed previously, the replacement of full membership with association status was their preferred policy. Argentina and Brazil may have opposed to this, but eventually a new agreement would have been negotiated, as the fact that all South American countries enjoy a deal with Mercosur suggests. On top of that, exporters to Mercosur markets, rather surprisingly, supported the negotiations with the US.

More recent developments also lead to question the central importance usually assigned to Mercosur membership. In 2015, "the (US PTA) debate was re-edited in the same terms and with the same actors, but this time about the Trade in Service Agreement (TISA)" (Garcé et al., 2016, p. 102), a services-only proposal led by the US and the EU. The FA government, again headed by Vázquez, entered the negotiations encouraged by Astori, who was again appointed Finance Minister, and his economic team. For them, TISA represented export opportunities in the emerging global services sector (El Observador, 2015). But the majority of FA parties, through both cabinet members and lawmakers, raised objections. They argued that TISA could trigger the liberalization of the telecommunication and fuel sectors, which regarded inconvenient, and prevent the state from supporting entrepreneurs in the tech sector (Uval, 2015). They were again backed by FA members of the developmental epistemic community, who in a public letter asserted, using Chang's (2002) expression, that these sorts of deals kicked away the ladder of development (La Diaria, 2015). As a result, Vázquez withdrew from the negotiations. Crucially, unlike a PTA, TISA did not affect the CET at all, so Mercosur members could not object if Uruguay wanted to join the deal (indeed Paraguay continued at the negotiating table). Nevertheless, the country opted out of TISA negotiations, driven again by a view of economic development that was majoritarian within the government coalition. Therefore, while acknowledging some role to Mercosur in the political debate towards the PTA with the US, the conclusion is that the ideas about economic development held by the majority of FA seem to explain, either alone or reinforced by the impact of Mercosur membership, both decisions.

\section{Comparison}

As seen in section 3, Chile and Uruguay were two open economies that did not face heavy external pressures to sign a PTA with the US, but they nonetheless followed different paths. Likewise, the government coalitions in both countries appealed to similar constituencies, yet they differed in their decisions. Furthermore, as the case studies show, the evidence does not reveal consistent patterns of interest representation that may explain why policymakers decided the way they did it. This is reinforced by the fact that in both cases the initiative to pursue a PTA came from government officials in the finance 
ministries, with no precedent demands from business associations. These officials in both countries were seeking to achieve what it is commonly mentioned in the literature: improved market access conditions, to overcome domestic resistance to market reforms or lock-in previous market reforms, and to use the agreements as commitment devices to attract additional inflows of FDI. However, this does not explain why their proposal was successful in Chile but failed in Uruguay.

Another similarity is that Concertacion and FA shared the same position in ideological terms within their political systems: both run left-of-center governments, and their parties in Parliament covered everything from the left to the center of the parliamentarian spectrum. Nevertheless, upon a closer inspection it emerged that inside the respective coalitions different ideas on economic development were held. In Concertacion, economic officials of all parties converged on the view that the free-market model was the best path to economic development, and were part of the open regionalism consensus that guided trade policy. In FA, in contrast, there was not such consensus. Some, including those who occupied key positions in the Finance Ministry, held similar views than their Chilean counterparts, but the majority believed that tackling development challenges required more direct state interventions. This difference, as the case studies show, meant they assigned different meanings to the trade-related provisions demanded by the US, affecting the assessment about the convenience of a deal.

In Chile, Concertación governments, under both PDC and PSCh presidencies, did not interpret the reduction of policy space as a cost, or at least as one that overcame the benefits of a deal. This resulted in the active search of the PTA and even the prior promotion of trade-related chapters in agreements with other countries, in combination with unilateral liberal policy stances on some dimensions. In Uruguay, AU and its allies within FA agreed with this overall assessment, but MPP, PSU, VA and PCU shared a different view in which the policy space costs caused by the trade-related provisions of the deal were too onerous and the potential gains not as attractive. As a result, Chile joined a PTA with the US and Uruguay did not. Certainly, institutions also mattered. While Uruguay electoral system allowed a greater representation of voices within the government coalition, in Chile the binomial system excluded potential political forces, like the Communist Party, from having parliamentary representation. Nevertheless, similar parties like PSU and PSCh took different stances. And in broader terms, regardless of the reason of their presence of absence, the fact that different economic ideas prevailed in these leftof-center administrations led to different results in regard to the US offer.

\section{Conclusion}

The rise of alternatives to multilateralism in trade relations has been a salient feature of the international political economy in the last decades, with North-South PTAs occupying a central place among them. Scholars have pointed out that for developing countries these deals represent an intensified version of the bargain that took place at the Uruguay Round, and that the ones proposed by the US are the clearest examples. To understand why some decide the bargain is worth and others do not, they have relied mostly on structural and societal explanations. However, even acknowledging their explanatory value, there is variation in the LA region that cannot be accounted for without highlighting other, complementary reasons.

This paper proposed to pay attention to the ideas about economic development held by policymakers at the time of deciding. As the trade-related provisions that reduce the policy space generate uncertainty 
Nicolás Pose

Economic Ideas and North-South Preferential Trade Agreements in the Americas

over costs and benefits of a deal, these ideas help them to interpret the issues at stake and make a choice. But crucially, there are different sets of ideas which differ in the meaning they give to the policy space tools. Ideas which come from the structuralist school of thought regard policy space as crucial to encourage economic development, whereas ideas based on neoliberal or neo-institutional economic thought see the same policy space more as an impediment than as an advantage. As a result, they differ in the assessment of whether signing a PTA with the US is convenient to foster economic growth and development or not. The argument proposed is shown to be able to account for differing decisions in Chile and Uruguay, two cases unaccounted for by previous explanations. Admittedly, it has little to say about cases constrained by heavy external pressures, like most Central American countries. But it offers a novel explanation for those in South America that faced moderate external and societal pressures. The in-depth design allowed observing just two cases, but future work could assess its potential to explain more variation within and beyond the region.

More generally, as the trade agenda becomes more complex, with the inclusion of trade-related provisions that put regulatory, behind-the-border issues at the negotiating table, the paper highlights the potential of ideational approaches to the study of trade policy. Tariff and quota measures have relatively clear distributional consequences, thus most scholars have relied on rational explanations to account for them. In contrast, decisions regarding trade-related regulations often have more far-reaching and unpredictable consequences, so they are surrounded by uncertainty. In these scenarios, the presence of ideas that fulfil this uncertainty with different meanings can help us to understand why national governments in LA opt for different ways of dealing with the challenges of the global economy.

\section{References}

Abdelal, R.; Blyth, M. and Parsons, C. (eds.), Constructing the International Economy, Ithaca: Cornell University Press.

Agüero, F. (2005) 'El acuerdo de libre comercio Chile - Estados Unidos', Colombia Internacional 61(1): $50-62$.

Alcántara, M. and Luna, J. (2004) 'Ideología y competencia partidaria en dos post-transiciones: Chile y Uruguay en perspectiva comparada', Revista de Ciencia Politica 24(1):128-168.

Amsden, A. (2001) The Rise of 'The Rest': Challenges to the West from Late-Industrializing Economies, Oxford: Oxford University Press.

Astori, D. (2005, May 13). 'Queremos crecer haciendo justicia, queremos crecer para hacer justicia.' El Espectador, retrieved from http://www.espectador.com/economia/42511/queremos-crecerhaciendo-justicia-queremos-crecer-para-hacer-justicia

Babb, S. (2003) 'The IMF in Sociological Perspective: A Tail of Organizational Slippage', Studies in Comparative International Development 38(2): 3-27.

Baccini, L. and Dür, A. (2012) 'The New Regionalism and Policy Interdependence', British Journal of Political Science 42(1): 57-79.

Baldwin, R. (1993) 'A domino theory of regionalism', NBER Working Paper.

Baldwin, R. (1997) 'The Causes of Regionalism', The World Economy 20(7), 865-888.

Barnett, M. and Finnemore, M. (2004) Rulers for the World. International Organizations in Global Politics, Ithaca: Cornell University Press.

Barreda, M. (2011) La calidad de la democracia. Un análisis comparado de América Latina', Política y 
Latin American Journal of Trade Policy 4 (2019) - Universidad de Chile

gobierno 18(2): 265-295.

Babayev, B. (2015) 'The Rise of New Institutional Economics and Assessment its Contributions to the Post Washington Consensus', The Journal of Economic Sciences: Theory and Practice 72(2): 87-97.

Bergara, M. (2003) Las reglas de juego en Uruguay. El entorno institucional y los problemas económicos, Montevideo: DECON-Trilce.

Blyth, M. (2002) Great Transformations: Economic Ideas and Institutional Change in the Twentieth Century, New York: Cambridge University Press.

Buquet, D. and Chasquetti, D. (2004) 'La democracia en Uruguay: una partidocracia de consenso', Politica 42 (2): 221-247.

Butelmann, A. and Meller, P. (1992) Estrategia comercial chilena para la década del 90. Elementos para el debate, Santiago: CIEPLAN.

Büthe, T. and Milner, H. (2008) The Politics of Foreign Direct Investment into Developing Countries: Increasing FDI through International Trade Agreements?', American Journal of Political Science 52(4): 741-762.

Chang, H. (2002) Kicking away the ladder. Development strategy in historical perspective, London: Anthem Press.

Chwieroth, J. (2007) 'Neoliberal Economists and Capital Account Liberalization in Emerging Markets', International Organization 61(2): 443-463.

Chwieroth, J. (2010) 'Shrinking the State: Neoliberal Economists and Social Spending in Latin America', in Abdelal, R.; Blyth, M. and Parsons, C. (eds.), Constructing the International Economy, Ithaca: Cornell University Press, 23-46.

CIACEX (2006) Evaluación Preliminar de un Posible Acuerdo con los Estados Unidos, Montevideo: CIACEX. Congress of Chile (2003) Boletin No 3318-10. Retrieved from http://webcache.googleusercontent.com/search?q=cache: xVHFslVo3kJ:www.senado.cl/app senado/index.php $\% 3 \mathrm{Fmo} \% 3$ Dtramitacion $\% 26 \mathrm{ac} \% 3 \mathrm{DgetDocto} \% 26$ iddocto $\% 3 \mathrm{D} 6051 \% 26$ tipo $\mathrm{doc} \% 3$ Dinfo $+\& \mathrm{~cd}=12 \& \mathrm{hl}=$ en $\& \mathrm{ct}=\mathrm{clnk} \& \mathrm{gl}=\mathrm{uk}$

Danza, A. (2006, January 5) 'Uruguay negociará en el 2006 tratados de "libre comercio" con Estados Unidos y con China para poder "darle trabajo a la gente". Búsqueda.

Debs, A. and Helmke, G. (2010) 'Inequality under Democracy: Explaining the Left Decade in Latin America', Quarterly Journal of Political Science 5(3): 209-241.

El Observador (2015, April 28) ‘Astori sugirió que quedar fuera del TISA generará desempleo’ El Observador, retrieved from http://www.elobservador.com.uy/astori-sugirio-que-quedar-fueradel-tisa-generara-desempleo-n303855

Gallagher, K. (2007) 'Understanding Developing Country Resistance to the Doha Round', Review of International Political Economy 15(1): 62-85.

Gallagher, K. (2008) 'Trading Away the Ladder? Trade Politics and Economic Development in the Americas', New Political Economy 13(1): 37-59.

Gallagher, K. (2013) The Clash of Globalizations. Essays on the Political Economy of Trade and Development Policies, London: Anthem Press.

Garcé, A. (2014a) ‘¿Réquiem para la derecha? La elección de 2014 y la izquierda que se viene’, in Garcé, A. and Yaffé, J. (eds.), La era progresista. Hacia una nueva estrategia de desarrollo, Montevideo: Fin de Siglo, 203-246.

Garcé, A. (2014b) 'Regímenes políticos de conocimiento: construyendo un nuevo concepto a partir de eventos seleccionados en políticas públicas del gobierno de Tabaré Vázquez', Revista de Ciencia Politica 34(2): 439-458.

Garcé, A.; Lopez, C.; D’Avenia, L. and Villegas, B. (2016) Regímenes políticos de conocimiento. Evaluando un 
Nicolás Pose

Economic Ideas and North-South Preferential Trade Agreements in the Americas

nuevo concepto a partir de la comparación de Chile y Uruguay, Montevideo: CSIC-UDELAR.

Garretón, M. (2005) 'Reflexiones en torno de la(s) izquierda(s) chilena(s) y el proyecto de país', Nueva Sociedad 197: 159-171.

Gathii, J. (2011) 'The NeoLiberal Turn in Regional Trade Agreements'. Washington Law Review 86: 421474.

George, A. and Bennett, A. (2005) Case Studies and Theory Development in the Social Sciences. Cambridge: MIT Press.

Goldstein, J. and Keohane, R. (1993) 'Ideas and Foreign Policy: An analytical Framework', in

Goldstein, J. and Keohane, R. (eds.), Ideas and Foreign Policy. Beliefs, Institutions, and Political Change, Ithaca: Cornell University Press, 3-30.

Guzmán, H. (2003, June 16) 'Firma del TLC Chile-Estados Unidos a nivel de gobiernos' ALAI, retrieved from http://www.alainet.org/en/node/107703

Haas, P. (1992) 'Introduction: Epistemic Communities and International Policy Coordination', International Organization 46(1): 1-35.

Hira, A. (1998) Ideas and Economic Policy in Latin America. Regional, National and Organizational Case Studies, Westport: Praeger Publishers.

Hoekman, B. and Kostecki, M. (2009) The Political Economy of the World Trading System: The WTO and Beyond, Oxford: Oxford University Press.

Horn, H.; Mavroidis, P. and Sapir, A. (2010) 'Beyond the WTO? An Anatomy of EU and US Preferential Trade Agreements', The World Economy, 33(11): 1565-1588.

Katada, S. and Solís, M. (2008) Cross Regional Trade Agreements. Understanding Permeated Regionalism in East Asia. Heidelberg: Springer.

La Diaria (2015, May 22) 'Declaracion publica', La Diaria, retrieved from https://ladiaria.com.uy/articulo/2015/5/declaracion-publica/

Lagos, R. (2008) 'Integración o fragmentación de América Latina. Perspectivas', in Lagos, R. (ed.), América Latina: ¿Integración of fragmentación?, Buenos Aires: Edhasa, pp. 591-608.

Manger, M. (2008) 'International Investment Agreements and Service Markets: Locking in Market Failure?' World Development, 36(11), 2456-2469.

Manger, M. (2012) 'Preferential Agreements and Multilateralism', in Heydon, K. and Woolcock, S. (eds), The Ashgate Research Companion to International Trade Policy, Farnham: Ashgate Publishing, 405-422.

Manger, M. and Shadlen, K. (2014) 'Political Trade Dependence and North-South Trade Agreements', International Studies Quarterly 58(1): 79-91.

Mansfield, E. and Milner, H. (2012) Votes, Vetoes, and the Political Economy of International Trade Agreements. Princeton: Princeton University Press.

Maxfield, S. (2003) 'The Dynamics of State-Business Relations in the Formulation of Latin American Trade', in Aggarwal, V.; Espach, R. and Tulchin, J. (eds.), The Strategic Dynamics of Latin American Trade, Stanford: Stanford University Press, 59-82.

Milner, H. and Judkins, B. (2004) 'Partisanship, Trade Policy and Globalization: Is There a Left-Right Divide on Trade Policy?', International Studies Quarterly 48(1): 95-119.

Montecinos, V. (2009) 'Economics: the Chilean story', in Montecinos, V. and Markoff, J. (eds.), Economists in the Americas, Cheltenham: Edward Elgar.

Moreno, M. (2010) 'Think tanks en Chile: Estilos y prácticas tecnocráticas en la formación de políticas', Enfoques 8(12): 103-125. 
Latin American Journal of Trade Policy 4 (2019) - Universidad de Chile

Ostry, S. (2002) 'The Uruguay Round North-South Grand Bargain: Implications for future negotiations', in Kennedy, D. and Southwick, J. (eds.), The Political Economy of International Trade Law, Cambridge: Cambridge University Press, 285-300.

Panizza, F. (2008) 'Economic Constraints and Strategic Choices: The Case of the Frente Amplio of Uruguay's First Year in Office', Bulletin of Latin American Research 27(2): 176-196.

Peinhardt, C.and Allee, T. (2012) 'Failure to Deliver: the Investment Effects of US Preferential Economic Agreements', The World Economy 35(6): 757-783.

Porras, J. (2003) La estrategia chilena de acuerdos comerciales: Un análisis político, Santiago: CEPAL.

Porzecanski, R. (2010) No voy en tren. Uruguay y las perspectivas de un Tratado de Libre Comercio con Estados Unidos (2000-2010), Montevideo: Random House Mondadori.

Quijano, J. (ed,) (2006) Aspectos de la inserción internacional del Uruguay: análisis y reflexiones, Montevideo: Presidencia de la República-OPP-COMISEC.

Quiliconi, C. (2014) 'Competitive Diffusion of Trade Agreements in Latin America', International Studies Review 16(2), 240-251.

Roberts, C. and Heydon, K. (2012) 'Trade in Services', in Heydon, K. and Woolcock, S. (eds), The Ashgate Research Companion to International Trade Policy, Farnham: Ashgate Publishing, 167-185.

Rodrik, D. (2014) 'When Ideas Trump Interests: Preferences, Worldviews, and Policy Innovations', Journal of Economic Perspectives 28(1): 189-208.

Rojas, F. (2015) Ideas y política exterior. El rol de las comunidades epistémicas en la participación de Chile en la Alianza del Pacifico, Tesis de maestría en ciencia política, Santiago: Universidad de Chile.

Rosales, O. (2003) 'Chile's Multidimensional Trade Policy', in Aggarwal, V.; Espach, R. and Tulchin, J. (eds.), The Strategic Dynamics of Latin American Trade, Stanford: Stanford University Press, 189212.

Rosales, O. (n.d) Tratados de libre comercio con la Unión Europea y Estados Unidos: Nuevas bases para el desarrollo. Unknown publisher. Retrieved from http://www.u.cursos.cl/ingenieria/2012/1/IN70Z/material docente/bajar?id material=4321 $\underline{35}$

Ryan-Collins, L. (2009) 'Power and choice in international trade: How power imbalances constrain the South's choices on free trade agreements, with a case study of Uruguay', LSE DESTIN Working Paper No 09-97.

Saad-Filho, A. (2010) 'Growth, poverty and inequality: From Washington Consensus to inclusive growth', DESA Working Paper No 100.

Salazar-Xirinachs, J. (2003) 'The Proliferation of Regional Trade Agreements in the Americas: An Assessment of Key Issues', in Aggarwal, V.; Espach, R. and Tulchin, J. (eds.), The Strategic Dynamics of Latin American Trade, Stanford: Stanford University Press, 116-157.

Sánchez-Ancochea, D. (2008) 'State and Society: The Political Economy of DR-CAFTA in Costa Rica, the Dominican Republic, and El Salvador', in Sánchez-Ancochea, D. and Shadlen, K. (eds.), The Political Economy of Hemispheric Integration, New York: Palgavre Macmillan, 171-200.

Schneider, B. (2004) Business Politics and the State in Twentieth-Century Latin America, Cambridge: Cambridge University Press.

Schonhardt-Bailey, C. (1991) 'Lessons in Lobbying for Free Trade in 19th-century in Britain: to Concentrate or Not', American Political Science Review 85(1): 37-58.

Scott, J. and Wilkinson, R. (2011) 'The Poverty of the Doha Round and the Least Developed Countries', Third World Quarterly 32(4): 611-627.

Shadlen, K. (2005) 'Exchanging Development for Market Access? Deep Integration and Industrial 
Nicolás Pose

Economic Ideas and North-South Preferential Trade Agreements in the Americas

Policy under Multilateral and Regional-Bilateral Trade Agreements', Review of International Political Economy 12(5): 750-775.

Shadlen, K. (2008) 'Globalization, Power, and Integration: The Political Economy of Regional and Bilateral Trade Agreements in the Americas', Journal of Development Studies 44(1): 1-20.

Silva, E (1998) 'Organized Business, Neoliberal Economic Restructuring, and Redemocratization in Chile', in Durand, E. and Silva, E. (eds.), Organized Business, Economic Change, and Democracy in Latin America, Miami: North-South Centre Press, 217-252.

Silva, E. (2002) 'Capital and the Lagos Presidency: Business as Usual?', Bulletin of Latin American Research 21(3): 339-357.

Silva, E. (2009) Challenging Neoliberalism in Latin America, Cambridge: Cambridge University Press.

Silva, P. (1991) 'Technocrats and politics in Chile: From the Chicago Boys to the CIEPLAN Monks', Journal of Latin American Studies 23(2): 385-410.

Simmons, B.; Dobbin, F. and Garrett, G. (2006) 'Introduction: The International Diffusion of Liberalism', International Organization 60(4): 781-810.

Symonds, R.; Burghi, W.; Seizer, R. and Puig, J. (2006) Posición conjunta respecto a la conveniencia para el Uruguay de negociar acuerdos comerciales con países de extrazona, Montevideo: Cámara de Industrias del Uruguay.

Solervicens, E. (2003) 'Impacto del tratado de libre comercio entre Chile y Estados Unidos', Chronique 03-09 Observatoire Des Amériques.

Solís, M.; Stallings, B. and Katada, S. (2009) Competitive Regionalism. FTA Diffusion in the Pacific Rim, Hampshire: Palgavre Macmillan.

Stallings, B. (2009) 'Chile: A Pioneer in Trade Policy', In Solís, M.; Stallings, B. and Katada, S. (eds.), Competitive Regionalism. FTA Diffusion in the Pacific Rim, Hampshire: Palgavre Macmillan, 118-138.

Uval, N. (2015, June 10) 'Demasiado Caro', La Diaria, retrieved from https://ladiaria.com.uy/articulo/2015/6/demasiado-caro/\#!

Valenzuela, S. (1995) 'Orígenes y transformaciones del sistema de partidos en Chile', Estudios Públicos 58(2): 5-80.

Woll, C. (2008) Firm Interests: How Governments Shape Business Lobbying on Global Trade, Ithaca: Cornell University Press.

WTO (2011) World Trade Report, Geneva: WTO.

Yaffé, J. (2005) Al centro y adentro: la renovación de la izquierda y el triunfo del Frente Amplio en Uruguay, Montevideo: Linardi y Risso.

Zoellick, R. (2002, December 5) 'Unleashing the trade winds', The Economist, retrieved from http://www.economist.com/node/1477509 